\title{
Opinion regarding chemical technology and its applications.
}

\author{
Akhilesh Kumar Singh* \\ Department of Mechanical Engineering, Sasi Institute of Technology and Engineering, Tadepalligudem, Andhra \\ Pradesh, India
}

Accepted on August 28, 2017

\section{Opinion}

Chemical technology and its application play a vital role in all branches of engineering and science. Now-a-days nanotechnology is fully based on chemical technologies which improve the strength with high reliability in many areas such as aerospace, construction, vehicles, etc. for that many researchers and scientists team working in laboratories so hard to collect valuable information from chemical products, which safe for lifetime career with its many diverse applications. Many new thighs come through research in the laboratories, testinstruments and from the manufacturing chemical products.

High-temperature rigid ceramic fiber boards are also made up of alumina-silica fiber chemicals which contain both inorganic and organic binders to improve handling strength and ensure board integrity at high service temperatures. These boards have uniform density, are light in weight, good in rigidity and modulus of rupture. These features make it well-suited for application on high temperature application such as muffle furnace. This insulating feature can also reduce the cooling rate of furnace and thereby improve the hardness of material.

In welding, to improve the weld penetration in TIG welding Activated Flux TIG (ATIG) welding and Flux Bounded TIG (FBTIG) welding had been used for a unique joining process. Fluxes are also used in both extractive metallurgy and for metal joining process. The numbers of fluxes which are used in welding process to improve the weld penetration in TIG welding process are $\mathrm{TiO}_{2}, \mathrm{SiO}_{2}, \mathrm{Fe}_{2} \mathrm{O}_{3}, \mathrm{Cr}_{2} \mathrm{O}_{3}, \mathrm{ZnO}, \mathrm{CaO}, \mathrm{MnO}_{2}, \mathrm{Al}_{2} \mathrm{O}_{3}, \mathrm{CO}_{3} \mathrm{O}_{4}$, $\mathrm{CuO}, \mathrm{HgO}, \mathrm{MoO}_{3}$, and $\mathrm{NiO}$, etc. were used according to parent base metal. Fluxes can be used in the form of single or mixed fluxes in welding. In ATIG process, a thin layer of activating flux is covered on weld surface of the joint and in FBTIG welding process, a flux coating is applied along the weld line on the top surface before welding. Care is taken to apply the coating in such a way so that a small clearance is maintained along the weld line from the center of joint. Flux plays an important role to enhance the penetration with the help of convection flow of liquid metal. The chemical properties of activating fluxes in welding, influences the weld metal physically, chemically and metallurgically.

Chemical technology and its applications also improve the efficiency of solar energy, in power generation by changing the chemical composition properties of material. These technologies help in making solar panel more flexible and lighter in weight which gives high performance.

Chemical technology in pharmaceuticals aid in medical devices and in medicine and also it helps to repair of damaged human tissue, bones and specific cells. Advance chemical technology and its application decrease the cost of products by decreasing the weight side by side improving the strength with high reliability according to the highest professional standards.

The modern chemical technology and its application are used in following areas:

- Chemistry leads to cutting edge improvements.

- Chemistry used in metal refining process

- Chemistry used in software field such as computing.

- Chemistry used in cell phones for touch screens.

- Chemistry in fiber, space age and paper technology.

- Chemistry used in waste water recycling and biomedical applications.

- Chemistry used in different energy and sustainability.

- Chemical technicians used in equipment manufacturing and techniques.

- Chemical technicians used in welding such as developing fluxes, soldering and brazing materials.

- Chemical technicians used in laboratories to research, develop, produce, and test chemical products etc.

\section{*Correspondence to:}

Akhilesh Kumar Singh

Department of Mechanical Engineering

Sasi Institute of Technology and Engineering

Tadepalligudem

Andhra Pradesh, India

Tel: +91-9612625040

E-mail: akhileshkr.singh@hotmail.com 